\title{
A Decade of Delivering Sustainable Coastal Zone Management: The Tay Estuary Forum
}

\author{
Laura M. Booth ${ }^{1} \&$ Robert W. Duck ${ }^{2}$ \\ ${ }^{1}$ Tay Estuary Forum, University of Dundee, Dundee, DD1 4HN, Scotland, UK \\ TayEstuaryForum@dundee.ac.uk \\ ${ }^{2}$ School of Social and Environmental Sciences, University of Dundee, Dundee, DD1 4HN, Scotland, UK \\ r.w.duck@dundee.ac.uk
}

\begin{abstract}
The Tay Estuary Forum (TEF) was established in 1997 with the aim of promoting the wise and sustainable use of the Tay Estuary and adjacent coastline of east-central Scotland. A decade ago, at the Littoral 2000 conference, the newly-formed TEF was described as being in a "formative" stage and evidently "aiming to promote a sustainable environment within an unsustainable system" (Burningham et al. 2000). This paper reflects on the achievements, developments and changes to the Partnership over the past decade and outlines the ongoing challenges it still faces. Scotland's network of Local Coastal Partnerships (LCPs) have seen changes in national policy over the past decade but local delivery issues are still very much the same as they were ten years ago with community engagement and voluntary participation vital to the success of the Partnerships. With the emergence of Scotland's Marine Act, the future of the LCPs in their current form may be uncertain, but their role in distilling national policy to the local level (and vice versa) is more essential now than ever before. As a well-established, integrated network, the Partnerships are well-placed to deliver this balance, given appropriate resources and funding. Despite a lack of long-term financial security, the TEF has persevered in gathering momentum since 1997; true partnership working has been cited previously as its greatest achievement (Finan and Duck, 2004). In April 2009 the TEF published a five-year Management Plan directing the work of the Forum over the years 2009-2014. The Plan evolved during a wide-ranging consultation with local stakeholders and will draw on the TEF's extensive, dedicated membership in delivering key social, environmental and economic objectives to this diverse and valuable coastal region in the future.
\end{abstract}

\section{Introduction}

Local Coastal Partnerships were set up in the UK in the early 1990s after an impetus from the Earth Summit in Rio (1992) and the UK's Biodiversity Action Plan commitment to develop integrated management strategies for a number of estuaries and firths. In 1993, a Scottish Natural Heritage (SNH) "Focus on Firths Initiative" was launched; responsible for the first group of Coastal Partnerships covering four major estuaries in Scotland (Moray and Solway Firths; the Firths of Clyde and Forth). The Tay Estuary Forum formed in 1997, following a conference hosted by the University of Dundee.

Through a strong sense of partnership working, built over the last thirteen years, the TEF has provided a mechanism for sustainable coastal management through information-sharing and discussion of issues, sometimes contentious, which affect the estuary and coastal region. The Forum provides an inclusive, accessible means of estuary-wide co-operation, which did not exist prior to its creation. Given the current climate of legislative change, the TEF remains a valuable, local mediator in resolving coastal issues and distilling European and National policies to the local level. 


\subsection{Tay Estuary Forum Region}

The TEF area extends from Milton Ness, Angus [British National Grid Reference NO 77006480] southwards to Fife Ness [NO 64000990] in east central Scotland, encompassing the $40 \mathrm{~km}$ long Tay Estuary as far upstream as its tidal limit at Scone, Perthshire [NO 11002600] and covers a minimum distance of $5 \mathrm{~km}$ offshore (Fig. 1).

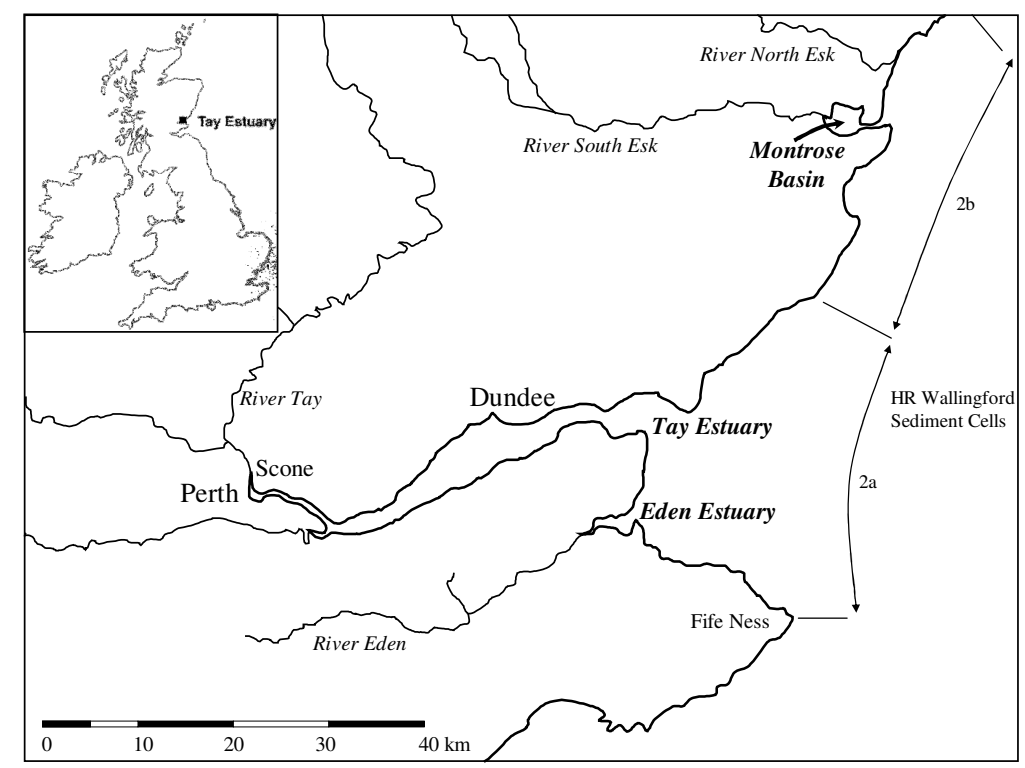

Figure 1: Map of the area covered by the Tay Estuary Forum - the coastline is coincident with Sediment Cells $2 a$ and $2 b$ of HR Wallingford (1997)

There are three major estuaries within the TEF region; the Inner Tay (12265 ha), Montrose Basin (842 ha) and the Eden Estuary in Fife (1047 ha). The Tay drains the largest area of any river in Scotland and has the highest freshwater inflow of any estuary in Britain. Montrose Basin, at the mouth of the River South Esk, is one of the finest examples of an enclosed estuarine basin in the UK. Compared with other UK estuaries, the Tay Estuary is relatively undeveloped, its south shore remaining predominantly rural.

The Tay Estuary is an area of exceptional environmental quality and is widely regarded as one of Europe's least polluted estuaries (Duck, 2005). Montrose Basin, the Tay and Eden Estuaries support nationally and internationally important populations of wildfowl and waders with approximately $10 \%$ of the world population of pink-footed geese wintering in the TEF region. This is recognised by their designation as Special Protection Areas (SPAs) under the European Birds Directive and as Ramsar Sites under the Ramsar Convention. The north shore of the Tay has the largest continuous stand of reed in Britain (410 ha) and Tentsmuir Point and Barry Buddon support extensive sand dune systems. The Rivers Tay and South Esk are renowned as some of the UK's most important spawning sites for Atlantic salmon and hold large populations of the endangered freshwater pearl mussel. There is an internationally important common seal population in the Tay Estuary and the otter appears to be making a successful comeback to Tayside and the Montrose Basin (Tayside Biodiversity Action Plan, 2002). 
Home to over half a million people, there are inevitable pressures along this stretch of coast where interactions between people, their environment and economic demands are constantly evolving. Overall, however, current environmental and economic demands are well-balanced in the region, creating a high level of amenity and water quality; a balance which the TEF works hard to sustain.

\subsection{Structure of the Tay Estuary Forum}

The TEF currently operates on a three-tier basis: It has a membership of over 450 organisations, groups and individuals with an interest in the estuary and coastal zone. This wider forum is regularly contacted via a quarterly newsletter and its members are invited to attend TEF events, such as field trips and the Annual Conference. A Steering Group, which meets every three months, guides and monitors the work of the Forum. The benefits of this regular review include: promoting accountability, ensuring a greater capacity to manage, improving project planning and promoting adaptive management.

The Steering Group currently comprises representatives from the four local authorities around the estuary: Angus, Dundee, Perth \& Kinross and Fife Councils; The Crown Estate, Scottish Environment Protection Agency, Catchment Tay Ltd, Royal Society for the Protection of Birds (Scotland), Forth Ports PLC, Montrose Port Authority, Scottish Natural Heritage, Tay Salmon Fisheries and the Universities of Abertay, Dundee and St Andrews. Finally, a Secretariat, which includes the Chair and Project Officer, drives the daily work of the TEF, housed at the University of Dundee.

The TEF is part of a wider network of seven Coastal Fora (and several other similar organisations) that exist around Scotland's coast as well as the rest of the UK: sharing a common aim to deliver Integrated Coastal Zone Management at the local level. The Scottish LCPs are connected by the Scottish Coastal Forum (SCF), which provides a platform for regular communication and collaboration between the Partnerships, and puts the work of the Fora into context at a national level.

\section{A Reflection on TEF Achievements}

Unlike other Coastal Partnerships in Scotland, the TEF is housed in a university, giving the organisation a valuable sense of neutrality. The TEF has therefore not aligned itself with any one Steering Group member who might potentially be seen to have a vested interest. Finan (2004) acknowledges the perception of the University of Dundee as an 'honest broker', encouraging member organisations, which might otherwise have been less inclined to engage with the Partnership. Table 1 lists some of the TEF's main achievements over the past decade. 
- Acts as an 'honest broker' engaging a wide range of stakeholders.

- Works to implement the principles of ICZM though a voluntary partnership

- Developing a network of communication and consensus building between stakeholders.

- Where appropriate the TEF provides input into local, national and international projects and consultations that can assist in delivering integrated and sustainable coastal management.

- Quarterly publication of the TEF Newsletter.

- Co-ordination and facilitation of an annual conference (April) for all the stakeholders around the Tay Estuary.

- TEF Website linked to other relevant sites.

- Production of 5 year Management Plan after a 1 year consultation highlighting the main issues within the TEF region and prioritising resolution of these issues.

- New TEF Leaflet 2010.
- Represented at local festivals and galas.

- Member of Tayside LBAP and Tayside Geodiversity.

- Member of Broughty Ferry Beach Management Group and Riverside Nature Park Group.

- Working with organisations such as RNLI and local police in raising awareness of wildlife crime and sea safety.

- Initiates and facilitates focused seminars and field trips relating to estuarine/ coastal issues.

- Promotes publication of technical papers on the Tay, as part of the Occasional Paper Series.

- Gives presentations to schools, community groups and other partnership organisations, on the Tay Estuary's environment and management.

- Provides advice and information on the Tay's resources for all partners and the public.

- Tay Estuary Forum represented at international and national conferences.

- Organises beach cleans with youth groups, industry and schools.

\section{Table 1: Summary of Tay Estuary Forum's key achievements to date} (from TEF Business Plan 2010/11)

\subsection{Management Plan}

In April 2009, the Tay Estuary Forum launched its five year Management Plan to guide the work of the Forum over the years 2009-14. The Plan is a non-statutory document, aimed at promoting future sustainable management in the Tay Estuary and along the adjacent coastline. It takes into account current and proposed local management initiatives and activities, identifying overlaps in policy where partnership working may be explored. It attempts to bridge gaps between strategies and aims to bring National and European legislation into a local focus. The document was drafted over 2008/9, using the TEF Theme Framework (2000, reviewed 2004) as a basis for identifying key tasks of the Coastal Partnership. After discussions at annual conferences and a period of consultation (attracting input from a wide range of stakeholders and individuals) a list of Actions was agreed upon. During 2009/10 the TEF has worked hard to achieve the "Year 1 Actions", listed in the Management Plan (http://www.dundee.ac.uk/crsem/TEF/), with progress reported on to 2010 conference attendees. The Forum will continue to explore all avenues of funding in implementing Developmental and Future Actions, as laid out in the Plan. By continually reviewing the document, the TEF will ensure that Actions are implemented as efficiently as possible (funding and resources allowing), and that the approach taken to delivering sustainable management of the Tay Estuary is done in a realistic and structured manner. The emphasis is for the Plan to remain dynamic; realistic in reflecting the changing needs of stakeholders around the Tay Estuary over time.

\subsection{Changes in Coastal and Marine Policy 2000-2010.}

A number of developments in coastal management are anticipated over the coming years, first and foremost with the emergence of Marine Scotland and the setting up of Scottish Marine Regions. Table 2 illustrates some of the key legislative changes and policy initiatives of the past decade that have played a part in shaping the remit, and future of LCPs. 


\begin{tabular}{|c|c|c|}
\hline Date & Policy Initiative & Description \\
\hline April 2010 & $\begin{array}{l}\text { Marine Scotland's consultation on Scottish Marine } \\
\text { Regions }\end{array}$ & $\begin{array}{l}\text { Creating more localised sense of ownership of marine } \\
\text { planning. }\end{array}$ \\
\hline March 2010 & Marine (Scotland) Act & $\begin{array}{l}\text { Providing a framework to help balance competing demands } \\
\text { on Scotland's seas. }\end{array}$ \\
\hline Feb 2010 & Marine Science Strategy & $\begin{array}{l}\text { Shaping, supporting, coordinating and enabling delivery of } \\
\text { world class marine science for the UK. }\end{array}$ \\
\hline Dec 2009 & River Basin Management Plans Published. & $\begin{array}{l}\text { To protect and improve the water environment developed in } \\
\text { consultation with organisations and individuals. }\end{array}$ \\
\hline Nov 2009 & UK Marine and Coastal Access Act & $\begin{array}{l}1^{\text {st }} \text { step towards a coordinated UK marine law, with a new } \\
\text { marine planning system and marine conservation powers. }\end{array}$ \\
\hline July 2009 & Marine Strategy Forum Established & $\begin{array}{l}\text { Bringing together delivery partners \& stakeholders with a } \\
\text { marine interest. }\end{array}$ \\
\hline June 2009 & UK Marine and Coastal Access Bill & $\begin{array}{l}\text { Proposing Marine Management Organisation as the UK } \\
\text { Government's principal delivery body in the marine area. }\end{array}$ \\
\hline April 2009 & Scottish Marine Bill introduced to parliament & $\begin{array}{l}\text { New legislative and management framework for the marine } \\
\text { environment. }\end{array}$ \\
\hline April 2009 & Marine Scotland Established & $\begin{array}{l}\text { Delivering integrated marine management functions - } \\
\text { science, policy development and delivery, compliance } \\
\text { monitoring and enforcement. }\end{array}$ \\
\hline $\begin{array}{l}\text { Dec 2008- May } \\
09\end{array}$ & $\begin{array}{l}\text { Consultation on Draft River Basin Management } \\
\text { Plans }\end{array}$ & $\begin{array}{l}\text { Public sector bodies, businesses and individuals working } \\
\text { together to protect the water environment. }\end{array}$ \\
\hline Sept 2008 & Inshore Fisheries Groups Piloted & $\begin{array}{l}\text { To improve the management of Scotland's inshore fisheries } \\
\text { out to } 6 \mathrm{~nm} \text {. }\end{array}$ \\
\hline July-Oct 2008 & Sustainable Seas for All & A Consultation on Scotland's first Marine Bill. \\
\hline July 2008 & $\begin{array}{l}\text { Marine Science Coordination Committee (MSCC) } \\
\text { set up }\end{array}$ & $\begin{array}{l}\text { to develop and implement UK Marine Science Strategy, and } \\
\text { to improve UK marine science co-ordination. }\end{array}$ \\
\hline June 2008 & EU Marine Strategy Framework Directive & $\begin{array}{l}\text { Establishing a framework for community action in the field of } \\
\text { marine environmental policy. }\end{array}$ \\
\hline May 2008 & Marine Historic Environment Consultation & $\begin{array}{l}\text { Sets out proposals for Scottish Ministers' policy for the } \\
\text { marine historic environment. }\end{array}$ \\
\hline April 2008 & $\begin{array}{l}\text { Scotland's Seas; Towards Understanding their } \\
\text { State }\end{array}$ & Informing development of the Scottish Marine Bill. \\
\hline Jan 2008 & Sustainable Seas Task Force & $\begin{array}{l}\text { Input into development of Scottish Government's planned } \\
\text { consultation on a Scottish Marine Bill. }\end{array}$ \\
\hline Nov 2006-7 & $\begin{array}{l}\text { Environment \& Rural Development Committee } \\
\text { Report }\end{array}$ & Inquiry into management of the marine environment. \\
\hline $2006-7$ & $\begin{array}{l}\text { SSMEI Phase III Pilots launched in Shetland, } \\
\text { Berwickshire, Clyde and Mull }\end{array}$ & Developing integrated Marine Spatial Plans. \\
\hline $2005-7$ & $\begin{array}{l}\text { AGMACS (Advisory Group on Marine and } \\
\text { Coastal Strategy) }\end{array}$ & $\begin{array}{l}\text { To provide better policy leadership and good governance in } \\
\text { Scotland's marine area. }\end{array}$ \\
\hline Aug 2005 & Scottish Executive: "Seas the Opportunity" & $\begin{array}{l}\text { Strategy for the long term sustainability of Scotland's coast } \\
\text { and seas. }\end{array}$ \\
\hline March 2005 & $\begin{array}{l}\text { Marine Climate Change Impacts Partnership } \\
\text { (MCCIP) }\end{array}$ & $\begin{array}{l}\text { Established to facilitate transfer of knowledge from the } \\
\text { scientific community to decision makers. }\end{array}$ \\
\hline March 2005 & DEFRA: "Charting Progress" Report & An integrated assessment of the state of UK seas. \\
\hline July 2004 & $\begin{array}{l}\text { SCF: A Strategy for Scotland's Coast and Inshore } \\
\text { Waters }\end{array}$ & $\begin{array}{l}\text { To implement integrated coastal zone management (ICZM) } \\
\text { processes in Scotland. }\end{array}$ \\
\hline Nov 2002 & $\begin{array}{l}\text { Scottish Sustainable Marine Environment } \\
\text { Initiative (SSMEI) }\end{array}$ & $\begin{array}{l}\text { To understand the nature, value, and management needs of } \\
\text { Scotland's marine environment. }\end{array}$ \\
\hline Aug 2002 & World Summit on Sustainable Development & Johannesburg- Progress on '92 Rio Earth Summit. \\
\hline May 2002 & DEFRA: Safeguarding our Seas & $\begin{array}{l}\text { Strategy for the conservation and sustainable development } \\
\text { of the marine environment. }\end{array}$ \\
\hline $\begin{array}{l}\text { May } 2002 \\
\text { (rev. 2006/7) }\end{array}$ & $\begin{array}{l}\text { EU Recommendation concerning Implementation } \\
\text { of ICZM in Europe }\end{array}$ & Main policy directions for promotion of ICZM in Europe. \\
\hline $2000(\& 2006)$ & OSPAR Reports & Assessing quality status of the marine environment . \\
\hline Dec 2000 & European: Water Framework Directive & $\begin{array}{l}\text { To improve and integrate the way water bodies are } \\
\text { managed throughout Europe. }\end{array}$ \\
\hline Sept 2000 & $\begin{array}{l}\text { European Commission Communication on ICZM: } \\
\text { A Strategy for Europe }\end{array}$ & $\begin{array}{l}\text { To improve implementation of a wide range of EU legislation } \\
\text { and policies in coastal zones. }\end{array}$ \\
\hline
\end{tabular}

Table 2: Legislative Advancements within Coastal and Estuarine Management since 2000

(KEY) Consultations Reports/Management Plans Organisations Legislation 


\section{Challenges}

Challenges facing Local Coastal Partnerships have been well documented, such as problems engaging stakeholders and lack of statutory powers (ITAD and Cordah 2002) and inability "to influence government policy" (Atkins 2004), but emphasis should not be placed on what hinders a Partnership (as this is largely still unchanged) but to focus on what LCPs have managed, and continue to achieve, despite these difficulties.

Many of the challenges facing Burningham et al. (2000) and Finan et al. (2004), both previous TEF Project Officers, have been overcome, although one long-term obstacle still faces the TEF (and all LCPs) today; a lack of long term financial security. Currently, the TEF still employs only one member of staff, the Project Officer (at 50\% Full Time Equivalent). The post is funded by contributions, of varying amounts, from most Steering Group members along with the newlycreated Marine Scotland. If given appropriate financial backing, Project Officers would be able to devote more time to "progressing the Forum's activities" (Burningham et al. 2000), rather than concentrating on exploring numerous (and sometimes fruitless) funding opportunities. McGlashan and Barker (2004) reiterate that "with more reliable funding sources and stronger/ more effective legislative powers, the LCPs provide excellent examples of delivering ICZM at the local level, where it really counts!" Despite many calls to re-visit the level of funding for LCPs (e.g. AGMACs 2007: 4.6.6.) the issue remains unresolved.

Burningham et al. (2000) identified several areas of weakness in the newly-formed Tay Estuary Forum, such as a lack of representation from "vital sectors of the coastal community, particularly the business sector and the fishing industry" as well as a "large gap between the Forum and the general public" (Burningham et al. 2000). These issues are common to many fledgling Partnerships and the TEF has worked hard to overcome them. Public participation in TEF matters is now very good, with Annual Conference audiences numbering 65 (or more) consistently since 2005. The quarterly newsletter also ensures a more constant level of participation between members, regularly being made aware of TEF progress. Publicity from beach cleans, workshops and the Annual Conference has raised the profile of the TEF, with TV and radio stations covering the conference as a "one-stop shop" for current estuarine and coastal issues for the Tay and beyond. A newly published leaflet will further raise the TEF profile as well as attending events such as local festivals and galas.

Links with the fisheries sector has improved, with Tay Salmon Fisheries represented on the Steering Group and South East Scotland Inshore Fisheries Group (SESIFG) now regularly attending TEF field trips, and speaking at the 2010 conference. Links have also improved with the business sector, with companies regularly using the TEF as a means for organizing teambuilding exercises such as beach cleans.

Many of the TEF objectives laid out by Burningham et al. (2000) have been successfully achieved, such as "increasing public awareness and publications". The TEF's Occasional Paper series attracts input from a variety of authors and issues; the latest of which addresses "Employer's Requirements for Graduate Skills in the Coastal and Estuarine Sector" (Shaw \& Kemp, 2010). Production of a "Management Strategy" (Burningham et al. 2000) has also been accomplished, driving forward the work of the TEF in the years ahead. The TEF has excellent links with Universities (with Abertay, Dundee and St Andrews represented on the Steering Group), providing opportunities for research and as a means of sharing information on current and proposed projects. The TEF has compiled its "meta-database" (Burningham et al. 2000), containing a large amount of information on the TEF region, in the form of publications, theses 
and reports. This provides a useful first point of contact for new project students, contractors and the general public.

\section{Conclusions}

Finan et al. (2004) stated it was "true partnership working between Steering Group members" that is perhaps the greatest achievement of the TEF. Strong relationships between individual Steering Group members have made it easier to facilitate information exchange and build trust between key organisations around the table. This is still the case, aided by the Partnership being hosted within a university.

The TEF is an adaptive Partnership and despite irregular funding contributions and comparatively fewer resources than other Local Coastal Partnerships in Scotland, it still continues to deliver, setting itself achievable targets and evolving to meet the changing needs of its coastline and population.

Certain indicators of the TEF's "health" include: a well-attended conference each year, a thriving Occasional Paper series, a growing Forum membership, and new organisations being welcomed to the table (such as the Ministry of Defence). The TEF is working as effectively now as it ever has done; every attempt is made to publicise Forum events, raising the profile of the LCPs wherever possible. TEF links with statutory bodies and local groups remain strong, addressing a wide range of issues; from biodiversity to beach management.

In conclusion, although the system may still be termed, "unsustainable" (cf. Burningham et al. 2000), with a myriad of changing policies (Table 2); the LCPs have been evolving over the past decade, learning through their own experiences. Through necessity, limited funding has made the Partnerships resourceful and efficient in delivering coastal zone management, on a budget. The TEF, as one of Scotland's smaller Coastal Partnerships, (in terms of staffing and funding resources) is therefore a good indicator, illustrating that, if given appropriate and secure levels of funding, so much more could potentially be achieved. The strong collaborative network within and between Coastal Partnerships, forms an ideal foundation on which to build for future coastal management in Scotland.

\section{References}

AGMACS (2007) Recommendations of the Advisory Group on Marine and Coastal Strategy. A Follow up to Seas the Opportunity: A strategy for the Long Term Sustainability of Scotland's Coasts and Seas. Scottish Executive.

Atkins, S.M. (1994) Focus on Firths Project Plan Scottish Natural Heritage Unpublished Report.

Atkins, S.M. (2004) ICZM in the UK: A Stocktake. HMSO, Norwich.

Burningham, H.; Duck, R.W.; Watt, A.M. (2000). Perspectives from a Newly- Formed Integrated Coastal Zone Management Voluntary Partnership: The Tay Estuary Forum (Scotland) Periodicum Biologorum 102, 101-105. 
Duck, R.W. (2005). Evolving understanding of the Tay Estuary, Scotland: Exploring the linkages between frontal systems and bedforms. In: FitzGerald, D.M. and Knight, J. (Eds.), High Resolution Morphodynamics and Sedimentary Evolution of Estuaries, Chapter 14, 299313, Springer, Dordrecht, The Netherlands.

Finan, K.J; Duck, R.W. (2004). Delivering sustainable coastal management in an unsustainable system: seven years of the Tay Estuary Forum (Scotland). (In): Littoral 2004, Delivering Sustainable Coasts: Connecting Science and Policy, EUROCOAST/EUCC, Aberdeen, Scotland, 2, 642-643.

HR Wallingford, Ltd; (1997). Coastal cells in Scotland: Scottish Natural Heritage Research, Survey and Monitoring Report. Wallingford, U.K: HR Wallingford, Ltd. No. 56, 136p.

ITAD Ltd; BMT Cordah Ltd (2002). Assesment of the Effectiveness of Local Coastal Partnerships as a Delivery Mechanism for Integrated Coastal Zone Management. Scottish Executive Social Research, Edinburgh, 95 pp.

McGlashan, D.J.; Barker, N.J.; (2004) The Voluntary Approach to Integrated Coastal Zone Management: Perspectives from Great Britain Littoral 2004, Delivering Sustainable Coasts: Connecting Science and Policy, EUROCOAST/EUCC, Aberdeen, Scotland, 2, 98-103.

Shaw, P.J.; Kemp, S. (2010) Employers' Requirements for Graduate Skills, Attributes and Knowledge in the Coastal and Estuarine Sector. TEF Occasional Paper Series: 4. http://www.dundee.ac.uk/crsem/TEF/

Tayside Biodiversity Action Plan (2002) http://www.taysidebiodiversity.co.uk

TEF Business Plan (2010/11) http://www.dundee.ac.uk/crsem/TEF/

TEF Theme Framework (2000, revised 2004). http://www.dundee.ac.uk/crsem/TEF/ TEF Management Plan 2009-2014: http://www.dundee.ac.uk/crsem/TEF/ 